Jurnal Ilmial

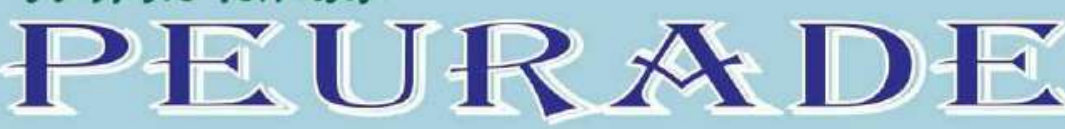

Vol. 5, No. 1, January 2017

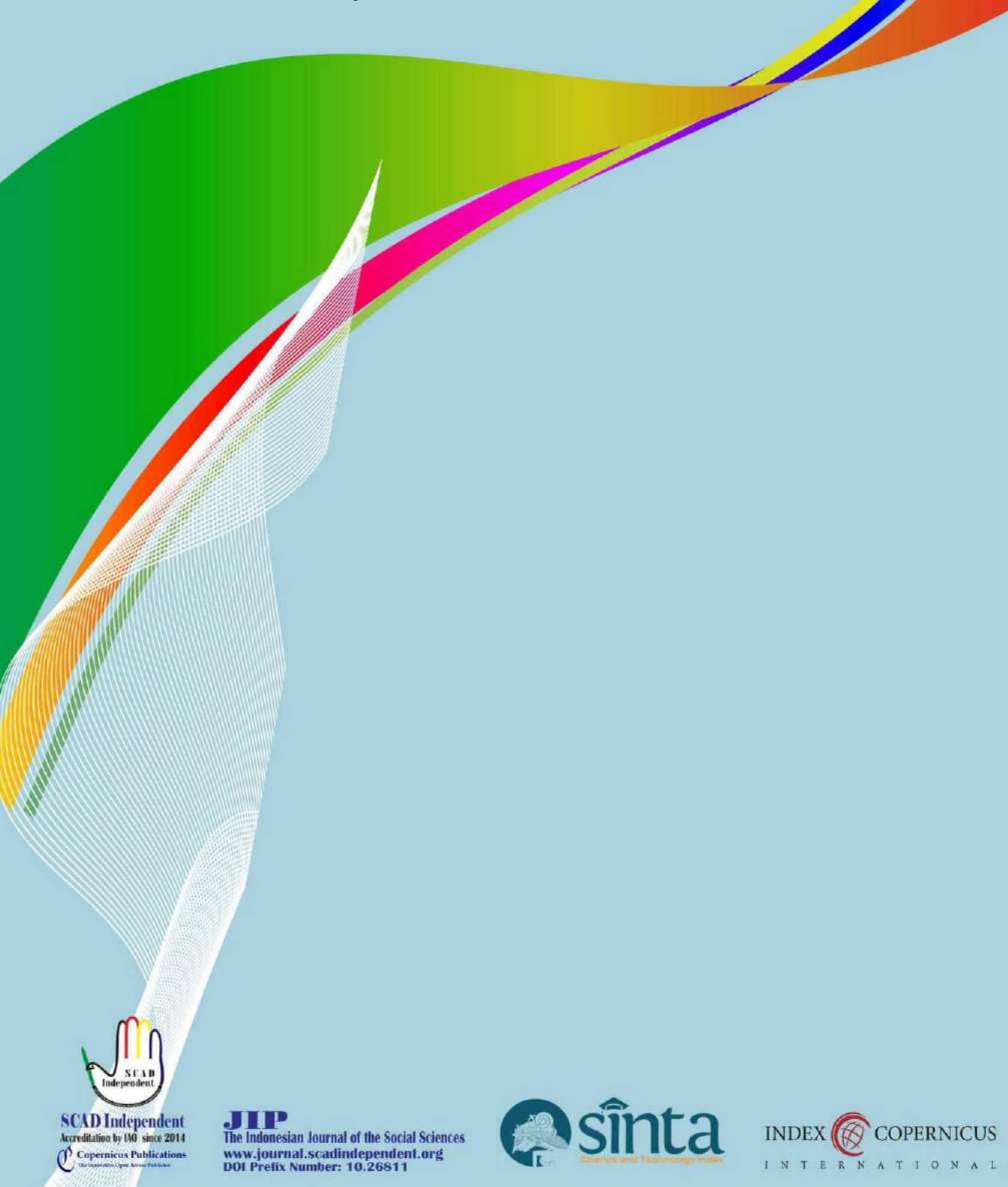




\title{
PARENTS' ROLES IN PREVENTING DRUG ABUSES AMONG TEENAGERS (A CASE STUDY IN BANDA ACEH)
}

\author{
Chairan M. Nur \\ Ar-Raniry State Islamic University, Indonesia \\ Contibutor Email: sari.rizki86@yahoo.com
}

Received: June 15, 2016

Accepted: June 27, 2016

Published: Jan 28, 2017

Article Url: http://journal.scadindependent.org/index.php/jipeuradeun/article/view/119

\begin{abstract}
Drug abuse has became a serious problem and related to many aspects of human beings physically, psychologically, socially, etc. It is also leaded to early death, physical disability, social lost, economic impact, etc. Therefore, it is highly recommended appropriated approaches in preventing drug abuse. One basic purpose of this research was to find out the parents' roles in preventing drug abuse among teenagers. That parent is obligated to educate their children as a main responsibility to God by having the children. Children are educated regularly in any occasions and conditions. The research applied the qualitative approach where the data collection was interview. The research location was in Banda Aceh. In addition, the samples of the study were unemployed and employed parents. The results of the research describes the efforts of parents in preventing their children from abusing drug, parents' role as supervisors, indeed, parents should know their children friends, solving family problems, collaborating with educational institutions (schools or universities), collaborating with home environment, morever, it could be understood that to stop drug abuse need all parties involvement. Ideally, it should be started from the family. It is believed family is the first "school" for children. The role of parents however is very important in preventing drug abuse as a role model, a guider, a supervisor, in addition, parents need to know their children friends, to solve family problems, to collaborate with educational institutions (schools or universities), and to collaborate with environment nearby the home.
\end{abstract}

Keywords: Parents Role, Drug Prevention, Children 


\section{A. Introduction}

At young age, there is lots of idealism that bridge many positive values, but there would also many negative values with. The fact that inside young generation, there is spirit of improved, creative, etc. The motivation of development is not only encouraging to positive way but also to negative way. The ability to manage the motivation positively is important to optimize the personal development to be an adult. The disability to manage the development motivation may lead to disorganized figure. One of the impacts is drug abuse.

Drug abuse has been known in most community as a vital problem and its complexity. Therefore, it is needed proportional, multidiscipline's, multisectors, indeed, active and sustainable parents' role, and consistent, Subagyo Partodiharjo (2004: 24). The increasing abuse of drug is not only in big towns but also in remote areas of this country, including Banda Aceh. The facts show that it has reached lower economy group of people to higher ones. The data describes that, most $f$ drug abuses were from age 13 to 25years old. It proves that young generation is targeted of drug dealers (Ida Listyarini Handoyo, 2004: 2).

A relevant survey on drug published on a local newspaper Serambi Indonesia concluded that Banda Aceh has been at an emergency of drug abuse that reached 7.000 people. The drug abusers were from various social backgrounds including students, wives, civil servants, military/police personnel, universities students, etc. The facts shown from a discussion of district parliament and Drug Preventing Agency (BNP) of Banda Aceh.

The teenager's demoralization has been influenced by man aspects and dominantly moral destruction resulted from friendship wrong doing. Man teenagers in Banda Aceh were trapped in misconception of friendship and consumed drug. They were difficult to differ good and bad yet. They were only able to think on short term situation. The influences of having enjoyments impacted themselves to involve in drug abuses. Therefore, it resulted in self demoralization. It was true that environmental influences played easily roles to disturb teenagers thinking, moreover, parents role to prevent and guide would be vital in addition to monitor the threat of drug abuses, (Moh. Shochib, 1998: 86 ). 
Wiranto (2007: 19) elaborates that the drug abuse was a serious problem that involved all aspects of human being. Considering the impacts of drug abuse, there should be appropriate preventions (not to test drug), secondary prevention (preventing abusers from being addictive) and tarsier prevention (rehabilitating addictive abusers).

\section{B. Method}

The research explored the parents' roles in preventing drug abuses among teenagers (a case study in Banda Aceh) by applying a qualitative approach, Moleong (2001: 5).The research was a field research where the data collected from field interviews.

Population is the whole research objects, Herman Warsito (1992 : 49).If a researcher would like to study all elements in a research location, so that the research would be population research. From the background analysis, to answer the questions, the research selected the parents of drug abuses teenagers in Banda Aceh, at minimum 5people mothers/father sand minimum of 5 teenagers who were drug abusers.

According to Sugiono (2010: 49), the population defined as generalized area that consisted of certain qualified and characteristic subjects stated by the researcher to be explored, at the mean time sample is a part of population. Sampling technique waspurposive sampling, where sampling was based on purpose, Husaini Ustman (1996: 47). The samples were 10 people, 5mothers/faherswho involved in drug prevention and 5 teenagers who were drug abusers. Data collection procedure was the important step in the research, Bima Walgito (1991: 54). The procedure was one in one interview with the selected samples.

\section{Research Findings and Discussion}

Parents' roles in preventing drug abuses among teenagers (a case study in Banda Aceh) were:

1. Parents as a Role Model

The urgency of parents roles in controlling their children development, if not, it may lead to disorganized of their future. A middle high school drug abuser who takes rehabilitation processes seriously in Banda Aceh. 
The abuser mother expressed her efforts to prevent drug abuse by giving good model to her children; therefore, it should be clearly shown practiced examples. For example, parents who are smoking should avid children $t$ be trusted. The interview results described that parents roles to prevent drug abuse through good examples at home or outside the home. In short, it ishould in line between stated and practiced. Morever, parents should clearly express the honesty in order to maintain the confident in front of children.

\section{Parents; the Resources of Correct Information}

Nopi said that the efforts given to prevent drug abuse by providing correct information on drug, the effects of drug abuse, in purpose to prevent children from testing drug, it is afraid that they know, they would try. It can be summarized that parents role in preventing drug abuses through information sharing openly to their children, which relevant to their age. We need to emphasize that they only consume prescribed medicines from a doctor. Parents should explain well about smoking, drinking alcohol, etc and its impacts on health. If a parent is a smoker, he should avoid children. By providing information about risks, it is expected that children would understand about the facts. Parents therefore should talk openly and clearly to their children about drug, it facts, and risks.

\section{Parents as "Guiders"}

Mawar said that efforts are being made to prevent drug by parents as guiders for the children, due to helping them to overcome various problems encountered and provide them choices, and realistic recommendations. By providing good teaching also become good deeds against children, through explaining negative impacts that led to his fall deviant acts such as using drugs, and telling about the punishment may be faced by drug abusers. Morover, to avoid them of being trapped, they should have regular family recreation, prayer or worship, acknowledged the error and apologized good practices from children to parent service versa parents to children. An example, that needs to be made as a habit. Indeed, the exploration toward the potential of children to develop through various activities. To develop children potentials, parents should train their confident, self-esteem and stable identity. 
The description above provides understanding that efforts to prevent drug where parents should be able to guide their children wisely and by not suppressing their self-esteem. In addition, it is encouraged that the child should be able to develop awareness, that the father or mother was a person of worth, which can be self-sufficient and capable in its own way to face her problems. If the child is not able to cope with her problems were difficult as drug problems, parents should be able to help discuss the issue through dialogue. In this case, assistances for children to cope with the pressures and negative influences of peers. So that the child will have support from their parents. Moreover, parents should be wise, by providing them good advices. The formal learning should be given every week in informal family gatherings such as during watching television, dinner, whereas these opportunities may lead to good understanding of children.

\section{Parents as "Supervisors"}

The most important effort dedicated by parents is to make sure the location of their children. There should also better regulations and consequences. This may lead to strengthening the control on them in order to prevent from drug abuse. Children would realize they are supervised by their parents. Of the elaboration above means that parents should prevent children by increasing supervising role. The limitation and supervision help significantly. By having stricter family regulations, parents may prevent children movements and behaviors. It also provides them responsibilities of their actions. It is important that although rules are stricter but there should be discussions and dialogues between parents and children.

\section{Parents and the Children Peers}

Musafir stated that practiced actions to prevent drug abuses by knowing and understanding children friends. It is highly recommended that parents should learn about friends of their children to avoid risks of drug abuses. It is clear that parents should build an understanding in preventing drug abuses through learning about friends of children. Ideally, they should be taken to home to meet and to learn the other 
family backgrounds such as their family, school, etc. Parents should build communication to understand their life. This effort would teach children to avoid misbehaviors and dishonest o parents and avoid drug.

\section{Resolving Family Problems}

Nevi said that to prevent drug abuses, parents should avoid family conflicts, because conflict in a family may lead children leave home and find other comfort friends or other solutions to calm down. They would be difficult to be home if there would be conflicts. It could be understood that parents efforts to prevent drug abuses by avoiding family conflicts so children may feel peace at home. It is recommended that parents should avoid any disputes or argues at home to prevent from children traumatic experiences. If it is needed, they may visit experts to discuss or solve the problems. There should be peaceful situation so that children would feel happy being at home.

\section{Collaboration of Educational Institutions (schools or universities)}

Dedicated efforts have been carried out to prevent drug abuses and one of them is building collaboration with educational institutions, the idea is to get closer supervision at schools from teachers. Therefore, it would be another model of prevention which students may afraid of violating rules by testing drug. The explanation above concerned on the understanding of how to prevent drug abuses through educational sector which parents may work closely with teachers. Indeed, educational institutions may design better prevention programs holistically. The collaboration and coordination need to involve multi stakeholders to achieve better impacts, such as lecturers, teachers, counseling teachers, students association, security personnel, canteen staff, administration staff, etc. It is also believed another practical prevention at schools.

\section{Collaboration with Home Environment}

Efforts to prevent drug abuses by collaborating environmentally with community. The role of neighbors, the communication with them may help to prevent children. We may build a systematical observation and supervision in a community to repent drug abuses. There should 
early prevention mechanism to detect any treats of drug abuses. Parents must well know of their children attitudes.

Drug abusers often try any sensations, hyperactive, easily disappointed, aggressive, and destructive. In addition, less involvement in extra school activities, less smart, often lie, rebel the regulations, often lead to drug abuses. It is recommended to keep praying and providing better efforts to prevent. There should intensive doctor consultation, religious discussion, to minimize treats. There should be well managed friendship to avoid impacts. The social rehabilitation and family supervising as well as training and skill development may also prevent from abuses. In short, family should continually maintain supervising activities if children have suffered from addictive.

From the description above, it could be understood that to stop drug abuses, all components should involve fighting for. The family as the frontline, the school, as other line, should provide better education and information for children. Parents should be a role model, a supervisor, etc and in collaboration with schools or universities in preventing drug influences.

\section{Conclusion}

The impacts of drug abuses on a person may vary on user's identity and situation. Generally, the impacts of drug abuses may be seen physically, psychologically, and socially.

Among the abusers, the dealers were motivated by internal and external factors which lead young generations become drug abusers. The following are internal factors: 1) For the style, for being braver, cooler, more creative, more relax, etc by influencing of certain substance; 2) For groups solidarity/which a group has stronger friendship among members. For instance, if a leader or a member use the drug, so that other members would forcedly should use as well; 3) For releasing the pain, a person of certain pain may cure with drug for the meantime; 4) For trial / curiosity, it is interested in effects of drug; 5) Followers, people have been victims due to following others. 
Externally, it is also a contributive factor toward drug abuses which family less concerned on children in term of educational and religious aspects. Parents must be the first line involve in educational development of young generation. It would be worse if parents did not seriously care their children. It is believed that a child with no good religious values would easily trapped in violation or abuses such as drug abuse, without family recognition.

A family as a small unit of a community should be a form of socialization processes from a teenager to an adult. The family should be as a main frontline in preventing kids from drug abuses. The drug abuses prevention should be started from and in the family. A prosperous and lovely family ideally should be a good space in prevention. Children should grow up in love and peace by getting informative opportunities from parents to learn and discuss wisely any conclusions on drug abuses preventions.

\section{Bibliography}

Daradjat, Zakiah. (1974). Pembinaan Remaja, Jakarta: Bulan Bintang.

Dhuhri, S. (2016). Art as A Cultural Instrument: The Role of Acehnese Art in Resolving Horizontal Conflict. Jurnal Ilmiah Peuradeun, 4(1), 89102.

Faruqi, Y. M. (2015). Role of Muslim Intellectuals in the Development of Scientific Thought. Jurnal Ilmiah Peuradeun, 3(3), 451-466.

Handoyo, Ida Listyarini. (2004). Narkoba Perlukah Mengenalnya, Bandung: Pakar Raya.

Hurlock, Tilizabeth. (1987). Perkembangan Anak, Jakarta: Erlangga.

Kaylene, P., \& Rosone, T. L. (2016). Multicultural Perspective on the Motivation of Students in Teaching Physical Education. Jurnal Ilmiah Peuradeun, 4(1), 115-126.

Meraj, M. A. (2016). Islamic Approach to The Environment and The Role's in The Environment Protected. Jurnal Ilmiah Peuradeun, 4(1), 1-14.

Moleong, Lexy J. (2001). Metodologi Penelitian Kualitatif, Bandung: Remaja RosdaKarya. 
Nurhasanah, N., \& Nida, Q. (2016). Character Building of Students by Guidance and Counseling Teachers Through Guidance and Counseling Services. Jurnal Ilmiah Peuradeun, 4(1), 65-76.

Partodiharjo, Subagyo. (2004). Kenali Narkoba dan Musuhi Penyalahgunaannya, Jakarta: Esensi.

Rouhana, H. (2015). Feminism National Identity. Jurnal Ilmiah Peuradeun, 3(3), 353-362.

Saifullah. (2015). The Internalization of Democratic Values into Education and Their Relevance to Islamic Education Development (Synthetic, Analytic, and Eclectic Implementation of John Dewey's Thoughts). Advanced Science Letters, Journal of Computational and Theoretical Nanoscience, 21 (7), pp. 2301-2304, DOI: 10.1166/asl.2015.6257

Salami, S. (2015). Implementing Neuro Linguistic Programming (NLP) in Changing Students' Behavior: Research Done at Islamic Universities in Aceh. Jurnal Ilmiah Peuradeun, 3(2), 235-256.

Santrock. (2007). Buku Ajar Tumbuh Kembang Remaja dan Permasalahannya, Jakarta: Sagung Seto.

Sarwono, Sarlito Wirawan. (1989). Psikologi Remaja, Jakarta: Raja Grafindo Persada.

Shochib, Moh. (1998). Pola Asuh Orang Tua dalam Membantu Anak Mengembangkan Disiplin Anak, Jakarta: Rineka Cipta, 1998.

Sugiono. (2010). Metode Penelitian Pendidikan, Bandung: Al-Fabeta.

Tabrani. ZA \& Masbur, M. (2016). Islamic Perspectives on the Existence of Soul and Its Influence in Human Learning (A Philosophical Analysis of the Classical and Modern Learning Theories). Jurnal Edukasi: Jurnal Bimbingan Konseling, 1(2), 99-112.

Tabrani. ZA. (2014). Islamic Studies dalam Pendekatan Multidisipliner (Suatu Kajian Gradual Menuju Paradigma Global). Jurnal Ilmiah Peuradeun, 2(2), 127-144.

Tabrani. ZA. (2014). Isu-Isu Kritis dalam Pendidikan Islam. Jurnal Ilmiah Islam Futura, 13(2), 250-270

Utsman, Husaini. (1996). Metode Penelitian Sosial, Jakarta: Bumi Aksara.

Walgito, Bimo. (1991), Pengantar Psikologi Umum, Yogyakarta: Andi Offset. 
Warsito, Herman. (1992). Pengantar Metode Penelitian, Jakarta: Gema Gramedia Pustaka Utama.

Wiranto. (2007). Ada Apa dengan Narkoba, Semarang: Aneka Ilmu.

Yusoff, M. Z. M., \& Hamzah, A. (2015). Direction of Moral Education Teacher To Enrich Character Education. Jurnal Ilmiah Peuradeun, 3(1), 119-132. 